\title{
花びらの染料紅花
}

\section{Carthamin Extracted from Petals of Safflower}

\section{1.はじめに}

古代の染料は、植物や動物から得た着色力のある抽出物 であった。お光らく最初は、数種類であったと考えられて いる。弚れらは Tyrian Purple(巻貝の分泌物から採った紫 色の染料)、Madder (茜の根を煮た液から採った赤色の染 料)、Kermes(ペルシャおよび近東諸国でカシワゃヒイラ ギなどに寄生する貝款虫から採った紫色の染料)、Woad (大 青と称する一種の藍)、Indigo(植物藍の葉から採った青色 の染料)、Safflower (紅花から採った黄色の染料 : 水に浸け ると黄色の色素が先に溶け出すので初期の頃は黄色だけを 使ったものと考えられる)などであろう ${ }^{11}$ 。兴の後、数千 年の間に 30 種類ほどになり、1856 年、最初の合成染料モ一 ブが出現するまで光の数と染法はほとんど変化しなかった。 弚の中で、赤色を与えるものとして、先ず植物系の茜、乥 して紅花、次いで動物系のコチニール、ラックなどが挙げ られる。

紅花は唯一、花弁を使用する天然染料である。咲き始め は黄色で、次いで赤味がさしてくる。一般に花びらで染め ると咲いている状況と異なる色になるが、紅花は咲いてい る時の色と染まる色が一致する。花弁から黄色と赤の色素 が抽出され、染料や着色料として使われる他、赤色色素は 口紅、ほほ紅などの化粧品として長く使用されてきた。ま た、花から抽出したエキスは主として婦人病に効く生薬と して古くから知られている。弚の種子には、リノール酸を 主成分とする油が含有され、現在、食用薬用として使用さ れている。最近では、食用色素として天然色素が見直され 一部の企業では、紅花の赤色色素カルタミンに注目し始め ている。

世界の紅花の栽培面積の $50 \%$ 以上がインドで、光のほ かメキシコ、米国などの乾燥地帯て栽培されているが、光 の多くは種子から油を採取するためである。わが国では、 紅花か渡来して以来、美しい赤色を染め出す染料として人

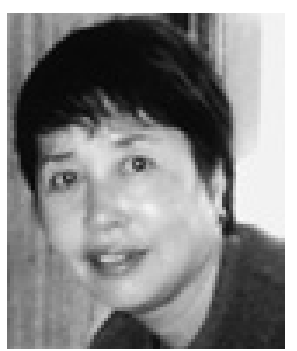

TAMAKO OTSU

昭和女子大学短期大学部 生活文化学科 教授、学術博士

T 154-8533 世田谷区太子堂 1-7

Tel : 03-3411-6075 Fax : 03-3411-2669

E-mail : tamago@swu.ac.jp

〈専門〉染色化学

〈趣味〉旅行、園芸
気が高く、江戶時代には高級染料として 100 トン近くの生 産があった。しかし明治になってからは合成染料に取って 代わられ、現在ではかつての産地であった山形県を中心に 少量が契約栽培されているだけで、日本で市販されている 紅花の大半は中国から輸入され、乥の一部が医療品として 利用されている。

最近では樣々な分野で安全性や環境への配慮から天然物 が見直されるようになり、研究も進んできている。本稿で は、天然染料としての紅花を取り上げ、光の沿革、花弁に 含まれている色素、染色方法、日本の伝統的な紅花染めで 使用されてきた烏梅、紅花染めした染色物の色調について 述べる。

\section{2. 紅花の沿革}

紅花はキク科の越年草で学名を Carthamus tinctorius L . (1753 年命名)という。属名は、染めるという意味のアラ ビア語に由来する。色素を取る花は、夏に枝の先に鮮黄色 の管状花か顗花をつくり、乥の後部分的に赤色に変化する。 染色用は総包片の縁に棘のある種類である(図 1)。关の歴

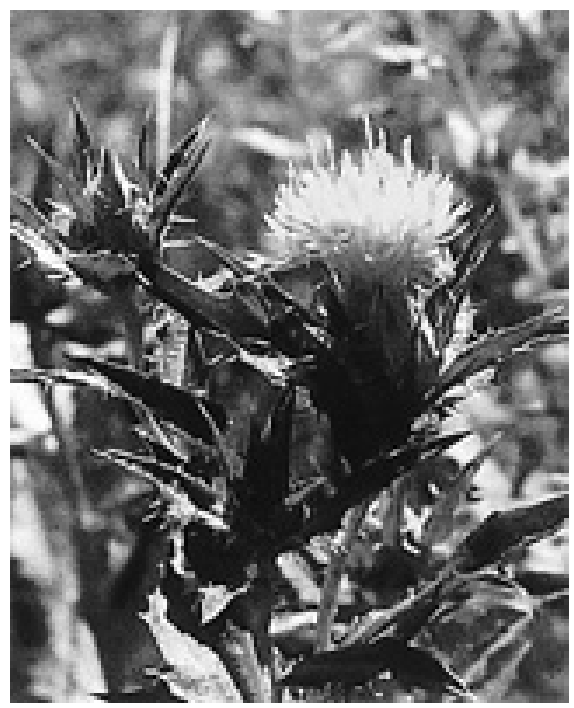

図 1 紅花

史は非常に古く、紀元前 2500 年頃のエジプトのミイラの 墓で発見された麻のリボンの黄または淡紅色が紅花で染め られたものであることが確認されている21。また、2700年 以上前のエジプトのサッカーラ遺跡から紅花の花びらと化 粧用に作られた赤色色素が出土している3)。1828年にエジ 
プトのテーベで、紀元前 3世紀にギリシャ文字で書かれた パピルスの写本が発見された。このうち幾つかはオランダ のライデンに売却され、他はスウェーデンのストックホル ムの王立科学院に送られ、後に保存場所にちなんで Papyrus Leidenis、Papyrus Holmiensis と名付けられた。 これらのパピルスは化学に関する版本で染色処方について も記してある。Papyrus Leidenisには、赤色を作る材料の 一つとして紅花の花弁が挙げられている4

紅花の原産地はエジプトのナイル川流域といわれ、光の 栽培法はシルクロードを経て中国に伝えられた。しかし、 西域においては年の染色技術は長い間、秘法とされ、中国 に伝えられたのは1世紀頃といわれている。日本へは、仏 教とともに伝来したとも、推古天皇の頃、高句麗の僧量微 がもたらしたともいわれている5゙。「れのあい」「くれな い」「くれないばな」「くれのはな」「べにのはな」「すえつ むはな」と呼ばれ親しまれてきた。日本に紅花が伝来して きた頃、藍という言葉を染料の総称として使っていたよう で、紅花のことを呉(中国)の国からきた染料という意味で 当初、「呉藍(くれのあい、くれあい)」と称したものと考 えられる。また、紅花の花が株の外側から内側に順に咲き その花を外側から摘んでいくことから「末摘花(すえつむ (はな)」とも名付けられた6)。源氏物語第六帖に乥の名の 登場人物が見られる。

古くから紅花で染色された衣服は灰で洗濯すると色が落 ちたり、日にあたると退色する性質があることがわかって いた。光こで紅花から「うつろう」「はかない」の言葉が 導かれた。万葉集には紅を詠んだ歌が多数ある。产の中の 一首「紅に染めてし衣雨降りてにほひはすともうつろはめ やも」は、美しい紅で染めた衣だから、雨が降ったからと いって、色はますます美しく照り映えるだけで、裉せるな んてことがあるはずがないという意味である。しかし、「う つろはめやも」-裉せるなんてことがあるはずがない-と いえるのは、裏を返せば、実際には紅花で染めた衣は雨(水) で色落ちして色が裉せることを作者が承知いるということ である。このように染色堅牢度が低いのにもかかわらず、 栽培に手間がかかり染色法も難解であり、何よりも年色 の美しいことから非常に高価で貴重なものとされ、明治に なって合成染料か輸入されるまでは、紅花は数少ない赤系 染料の花形であった。

延喜式の縫殿寮・杂隹染用度条には宮中の御服や調度品の 紅染法と紅花の貢納の規定があり、平安時代の貴族階級、 特に女性の憧れの色であったと考えられる。特に濃い紅色 は、高位の人にしか橆の着は許されず禁色となった。紅 色といっても、最も濃い色を「韓紅」、黄色色素の秨子や

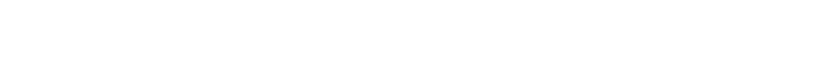
と呼び、紅花一斤で布一反を薄く染めたものを「一斤染め」 といった。

紅花がわが国に渡来してから、九州、中国、近畿、関東 など多くの地域で栽培されたが、中世末期からは紅花の栽 培に適した気候であったことから、現在の山形県の最上川
流域で栽培されるようになった。江戶時代には最上紅花が 最も発色が良いとされ、わが国の過半数を生産するように なり、紅花生産は米沢藩の財政を支えるほどに隆盛を極め た。収穫された紅花は後述する紅花餅となって京都に送ら れ、染料や京紅として使用された。当時の紅花の栽培から 紅花餅の売買までの過程を作業ごとに描いた「紅花屏風」 が、山形美術館、山寺芭蕉美術館に所蔵されている。日本 の特産品の番付を決めた「諸国産物見立相撲番付」では、 東の関脇が最上紅花で、西の関脇が阿波の藍玉とされ、こ れらが江戶時代の二大染料であったことがうかがえる。

近年になって天然染料が合成染料に光の座を奪われてか らは紅花も光の影を潜め、染織家などに供給するために少 量契約栽培されてきたが、昭和 40 年代後半には、紅花が 皮膚に対して抗炎症作用を持ち、血行を良くし肌の健康を 保つなどの特性が見直され、大手化粧品会社との間で大量 の契約栽培が行われ、一時は約 36へクタールの栽培を行っ たが、現在では、光の10分の1程度となっている。とこ ろで宮中の式典で用いられる服装の赤色は今でも山形産の 紅花が使用されているという。

\section{3. 紅花の色素}

紅花の花弁中には少量の赤色色素と大量の黄色色素が含 まれている。赤色色素はカルタミン(carthamin)、黄色色 素はサフラワーイエロー(safflower yellow) と呼ばれている。 カルタミンに関する研究は Preisser ${ }^{7)}$ 、Schlieper ${ }^{8)} 、 M a l i n^{9)}$ 、

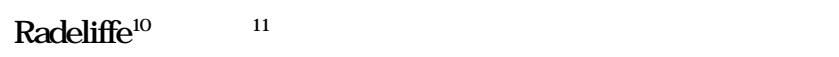
は未決定であった。关の後、亀高とPerkin は初めてカル タミンを結晶として分離した ${ }^{12)}$ 。1930年に日本の女性化 学者の草分け黑田はフラボノイド類の中のカルコン類とし て図 2(a)のような構造を提案した ${ }^{13)}$ 。光の後 Seshadri ら は図 2(b)のようなキノン構造を提案しカルタモンと命名 した14)。しかし、小野寺らは合成的な見地から図 2(c)の ような構造を提案し ${ }^{15)}$ 、現在ではこの構造が採用されてい る。

黄色色素は多成分よりなり、きわめて水に溶けやすい。 小野寺らは午の中の 3 種の色素を分離し、サフロミンA、 サフロミン B、サフロミン C と命名し、これらの構造(図<smiles>CCOc1cc(O)c(C(=O)/C=C/c2ccc(O)cc2)c(O)c1O</smiles>

(a)

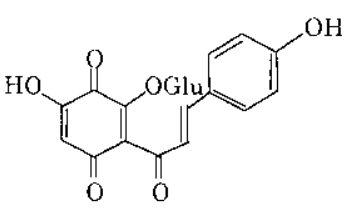

(b)

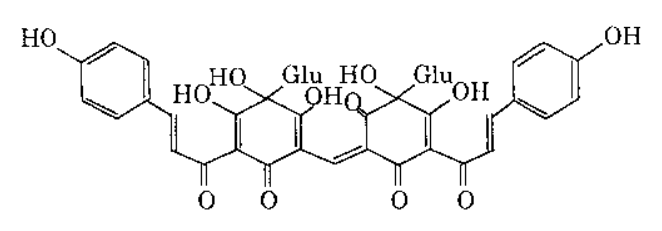

(c)

Glu=glucose

図 2 カルタミンの構造 


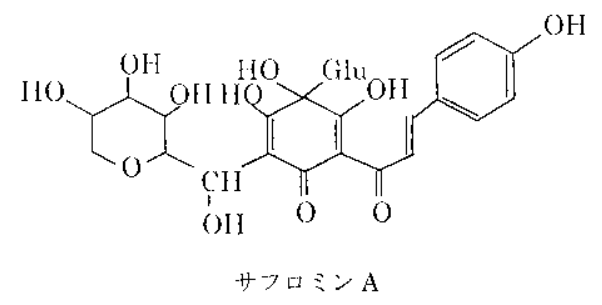

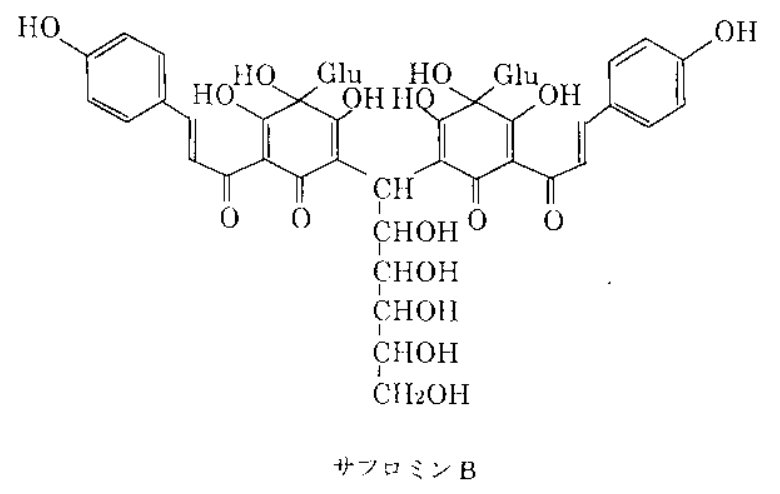

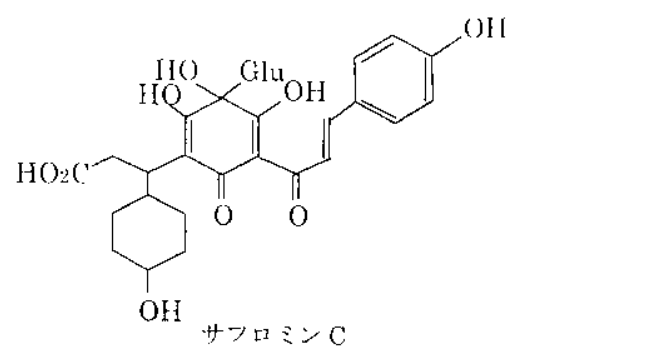

図 3 黄色色素の構造

3)を解明した ${ }^{16)}$ 。

紅花の咲き始めは黄色であるが、だんだんと赤色に変化 してくる。摘んだ花弁を箟に広げ、太陽にあてて乾燥させ るとより赤味を増す。また、黄色の花昪を指先で揉んでい るうちに赤くなることが古くから知られている。これらの ことは花弁の中にカルタミンに変化する前駆体が存在する ことを示唆している。下郡山らは黄色のカルタミン前駆体 を分離し、黑田のカルタミンの構造式に基づいて図 4(a)<smiles>COc1c(O)cc(O)c(/C=C\c2ccc(O)cc2)c1O</smiles>

(a)

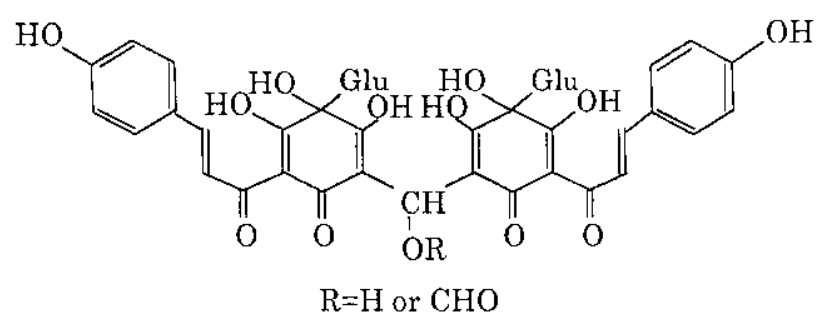

(b)

图 4 カルタミン前駆体の構造
のような構造式を報告している17)。小野寺らはすでに明ら かにしたカルタミンの構造から、前駆体の構造を図 4(b) のように推定している ${ }^{16)}$

伝統的な方法で紅花染めを行っている染織家山岸幸一氏 は、染色後、水酸化と称して自然流水で洗ったり、濃色を 得るための繰り返し染色では繰り返しの間隔を1ヶ月程度 と長くしたり、染色後、1年間ほど保存し寝かせてから使 用したりしている3)。これらの処理は、カルタミンととも に染着したカルタミン前駆体をカルタミンに変化させる効 果があるように思われる。

\section{1 色素の抽出と染色方法}

染色には花弁の乾燥したもの(散花)を产のまま使用する 場合と紅花餅(花餅、紅餅ともいう)を使用する場合がある。 紅花餅は中国で作られていたが、わが国でも江户時代に作 られるようになり、紅花餅を使った染色が盛んに行われる ようになった。

紅花餅は、黄色色素を水でよく洗い流し搾った後の花弁 を小さな団子状に丸め、これをのばして煎餅状にして、筵 の上に並べ弚の上に筵をか心汇せて発酵させた後、乾燥した ものである。散花よりも紅花餅を使用して染色したほうが 深い赤色になるといわれ、弚の実験結果が報告されてい る6)。このことは、発酵させる過程でカルタミン前駆体が カルタミンに変化し、カルタミンの純度が高くなったため と考えられる。

紅花の花弁には前述したように何種類かの黄色色素と赤 色色素カルタミンが含まれている。赤色色素を得るには、 黄色色素が水に、赤色色素がアルカリ性の水に溶ける性質 を利用する。先ず、中性の水に花弁を浸けて黄色色素を抽 出する。さらに花弁から黄色色素を水でよく洗い流した後、 $\mathrm{pH} 10.5$ 程度のアルカリ性水溶液でカルタミンを抽出する。 この抽出液に酸を加えて中和するとカルタミンが析出して 赤色に変色する。この中に纎維(絹)を入れて染色する。こ の時、黄色色素が残存していると黄味がかった赤色に染ま る。セルロース系の繊維には黄色色素が染着しないので、 セルロースで黄色色素を除去することができる。酸で中和 したカルタミン抽出液にセルロースを入れてカルタミンを 吸着させた後、アルカリ性の水に浸けてカルタミンを溶出 し、これを酸で中和して絹を染めると黄味の少ない赤色に 染めることができる。延喜式の用度の条文にある紅花染め における「䴳」の役割はセルロースと同じといえるだろう。 黄色色素が完全に除去できず残留している染液で染色す る場合、染色温度が高いと黄色色素の染着速度が速いため 黄色色素が多く染着する結果、黄色味がかって染まってし まうと長嶋らが ${ }^{18}$ 報告している。紅花の染色は昔から「寒 紅」といわれ、気温の低い時期に讶えた色が出るとか、染 色温度が低いほうが深い赤に染まるといわれているが、光 の理由は長嶋らの実験結果から説明できよう。

伝統的な染色法では、染色後、さらに発色あるいは色素 
の定着のため酸性の水中で 15〜30 分間繰る。すると色が 讶えて鮮やかになるといわれている。

カルタミンを抽出するためのアルカリ刘としては炭酸力 リ、炭酸ソーダなどが、中和するための酸としては酢酸、 クエン酸などの化学薬品か現在では使用されているが、伝 統的な染色法では、アルカリ剂として草灰、菜灰が、酸と して米酢や烏梅が使用されてきた。伝統的な方法で染色す る現代の染織家は、中和のためには米酢と烏梅を適宜用い ているが、最後の酸処理では、鮮明な赤色にするためとの 理由で烏梅を使用している。

\section{2 烏 梅}

六朝末、後魏の実用農書「斉民要術」の紅花の項には、 染色には安石榴と乳酸か酸として使われていたことが記さ れている ${ }^{19)}$ 。安石榴の栽培がペルシャからシルクロードを 東へと広がっていったことから、紅花の染色技術の伝播も 同樣と考えられる。しかし、わが国における伝統的な紅花 の染法では、酢が用いられ江戶時代には烏梅(図 5)が多く 用いられるようになった。

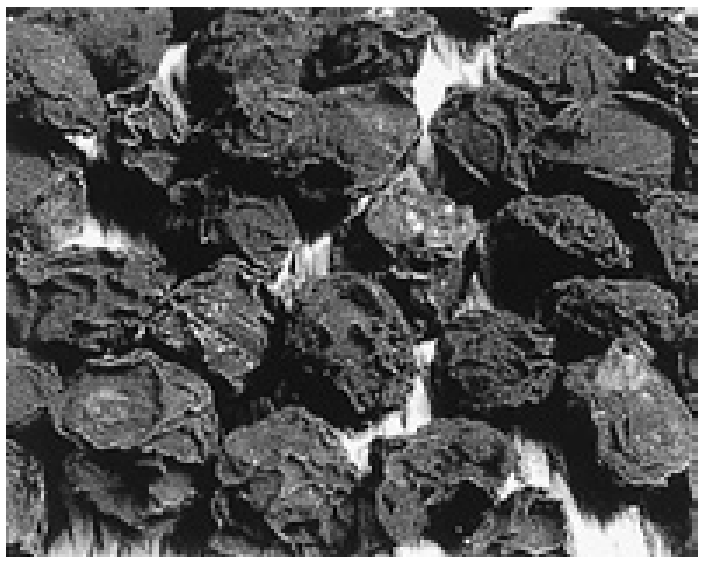

図 5 烏 梅

烏梅の製造法についても「齐民要術」に記されおり、日 本には遣唐使が伝えたとの説もあり中国から伝来したと考 えられる。烏梅は、黑梅とも呼ばれ、梅の実を煙で燻した もので、延喜式 37 典薬寮の条に「烏梅丸」の名が見える ように主に薬用として用いられたものと考えられる。1713 年刊行の百科事典「和漢三才図会」には烏梅の製造法か記 され20)、光の産地として備後の三原が挙げられている。

18世紀後半になると、梅林で有名な現在の奈良県月ヶ 瀬でも烏梅を作るために梅樹が植えられ、烏梅の生産量が 伸びた。もともと月ヶ瀬の自然環境が梅樹の生育に適して 古くから梅樹が多かったこと、烏梅が高価で収入がよかっ たことが本格的な烏梅の生産を始めるきっかけとなったも のと考えられる。月ヶ瀬の烏梅は薬用としてではなく紅花 染め用として使われた。江戶時代に最上紅花が京都に送ら れたように、烏梅も京都に送られ紅花染めに用いられた。 しかし、明治になり合成染料か輸入されるようになると、 乥れまで紅花染めに必須であった烏梅の需要は急速に衰退 し、多くの烏梅生産農家は養虫や製茶業に転業した。現在
では月ヶ瀬の中西喜一氏が日本において唯一人、烏梅作り を行っている。年間 170Kg を生産し、光の8割が染色用、 2 割が薬用として出荷されている20)。

烏梅の製法 ${ }^{21)}$ (以下のようである。梅拾い: 完熟して地 面に落ちた梅(落ちたばかりの黄色く色づいている梅で、 触るとまだ硬いもの)を集める。煤まぶし：鹳や鍋の底に ついた煤を集めておく。梅を吊り下げた箕に入れ、水を打っ て煤をかけ、箕をゆすり、均一に煤をつける。窯焚き：煤 をまら゙した梅を簾に並べる。地面に深さ $70 \mathrm{~cm}$ の穴を掘り、 これを窯とする。窯の底で柴や割木、籵殻を焚く。窯の上 部に簾を置き、全体に筵をか心゙せ、上から水をまき一尽夜 蒸し焼きにする。乾燥 : 燻蒸後、1～2週間天日で乾燥さ せる。

染色では、烏梅を熱湯に浸し光の上澄液(クエン酸を多 く含む)を酸として用いる。江戶時代になると紅花染めに 何故、烏梅が用いられるようになったのか不明であるが、 烏梅を使用すると深く美しく染まるとの経験が影響してい るものと思われる。

\section{5 . 酸の種類が色調に及ぼす影響}

伝統的な染色法で紅花染めをする場合に用いられる酸と して烏梅、米酢が知られており適宜用いられてきたことは 前述した通りである。特に染色後の酸処理では経験的に色 を深く鮮やかにするために烏梅が良いとされている。光こ で筆者は烏梅を使用すると他の酸と比較して色調にどのよ うな違いが生じるのか調べるために、烏梅、クエン酸、酢 酸をカルタミン抽出のために用いる中和剂および染色後の 酸処理剂として用いた。烏梅は熱湯に浸けて一晚放置後、 濾過して得られた濾液(以下烏梅) を用いた。いずれの酸も 同一の pH の水溶液に調整し使用した。

染液は、図 6 に示したように花弁から直接抽出する方法 と更に黄色色素を取り除くため、セルロースパウダーを用 いる抽出方法によって調製した。

染色は絹羽二重を 2 枚、調製した 6 種類の染液で浴比 $50: 1$ 、温度 $15^{\circ} \mathrm{C}$ で1時間染色した。染色後、2枚の絹布

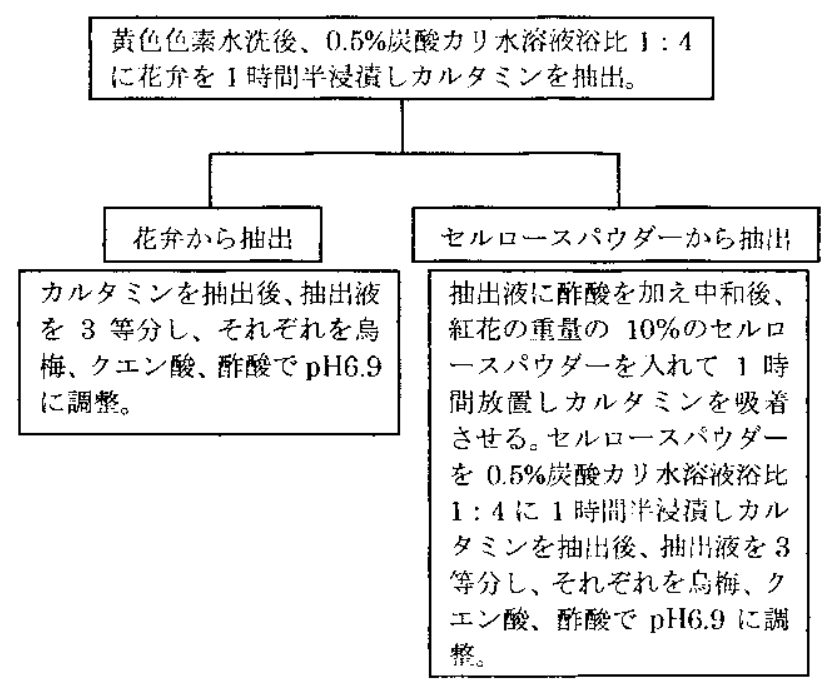

図 6 カルタミンの抽出 
のうち 1枚は水洗し乾燥した。もう1枚は、中和に用いた 同じ酸の水溶液 (pH 3.4)で浴比 $50: 1$ で 15 分間繰りなが ら処理した後、水洗し乾燥した。

表 1 は 12 種類の染色試料をまとめたもので、肉眼によっ ても色調に差があることが十分認められた。

測色色差計(日本電色工業製)を用いて基本色に対する色

\section{表 1 染色試料}

\begin{tabular}{|c|c|c|c|c|}
\hline \multirow{2}{*}{ 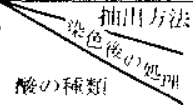 } & \multicolumn{2}{|c|}{ 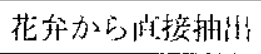 } & \multicolumn{2}{|c|}{ 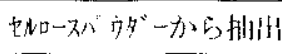 } \\
\hline & 我沉 & 酸处时! & 水洗 & 婹处叫! \\
\hline 具树 & 0 & 0 & (1) & 0 \\
\hline タコン䎟 & $\triangle$ & $\boldsymbol{\Delta}$ & $\triangle$ & $\Delta$ \\
\hline 酶酸 & $\square$ & $\mathbf{\square}$ & $\nabla$ & $\nabla$ \\
\hline
\end{tabular}
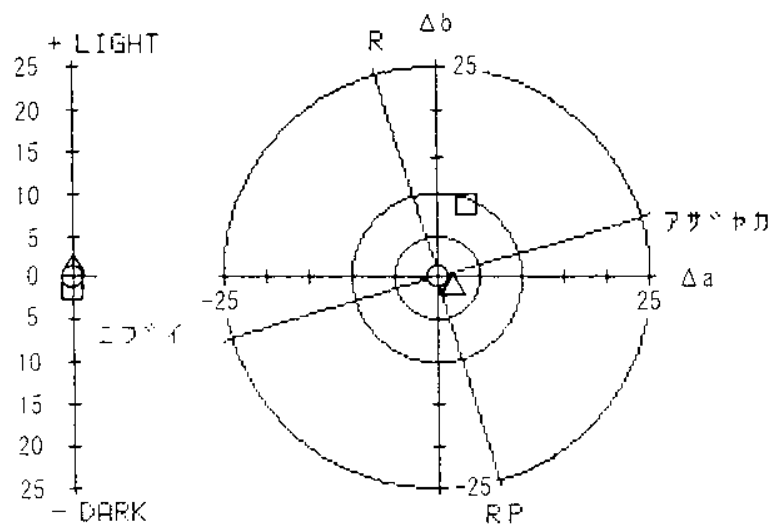

图 7 直接抽出・水洗の場合

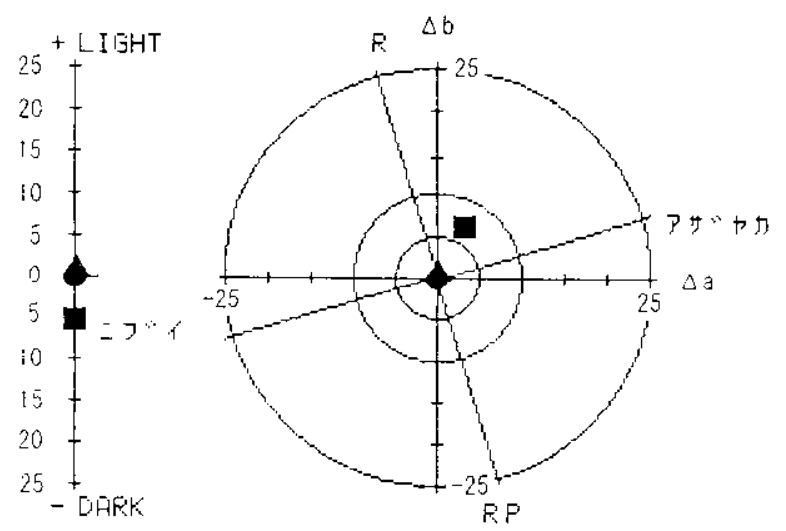

図 8 直接抽出・酸処理の場合

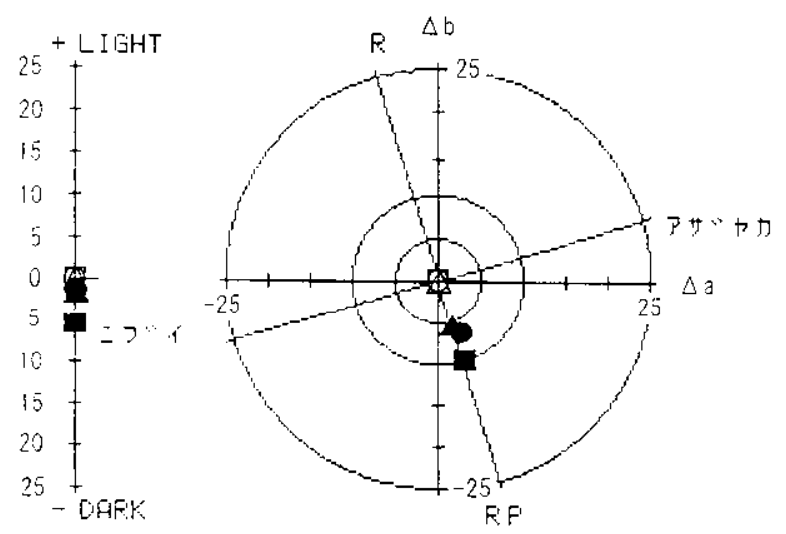

図 9 直接抽出・水洗と酸処理の比較
調の差を偏色判定図により求めた。図 7〜9は花弁から直 接抽出したカルタミンで染色した場合、图 10〜12セルロー スパウダー抽出の場合である。図 7、8、10、11 は烏梅を 用いた場合を基本色に、図 9、12 は染色後、水洗のみの場 合を基本色に測定した。図 13 は直接抽出を基準にセルロー スパウダー抽出を比較したものである。

これらの測定結果から以下のことが明らかになった。(1) 烏梅と試薬のクエン酸を用いた場合は、色調にほとんど差 か認められない。これは烏梅の主成分がクエン酸であるこ とから説明できる。(2)直接抽出では、染液の $\mathrm{pH}$ が同じ であっても酢酸を用いた場合には、赤方向への偏りすなわ ち黄味か強くなり加えて濃色に染まる。微量に残存する黄 色色素が、烏梅、クエン酸を用いると染着しないが、䤀酸
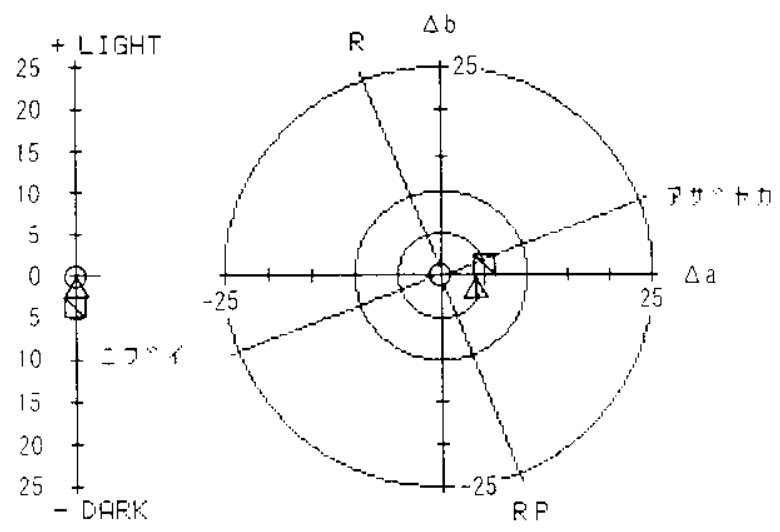

図 10 セルロースパウダー抽出・水洗の場合
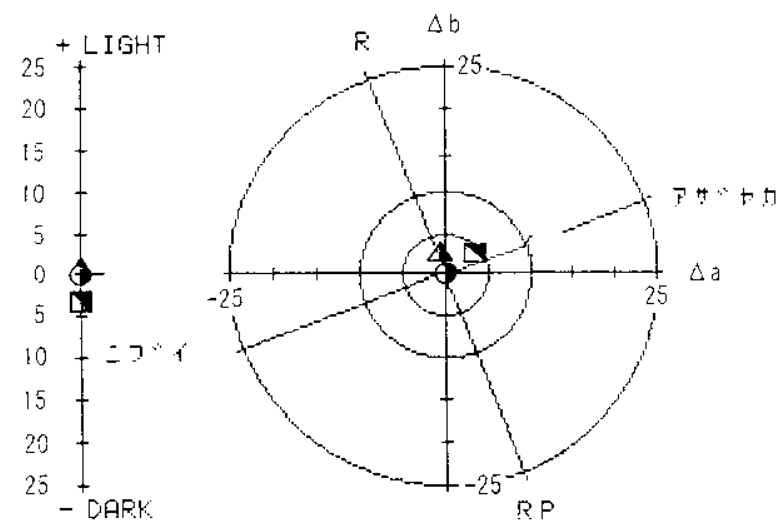

図 11 セルロースパウダー抽出・酸処理の場合

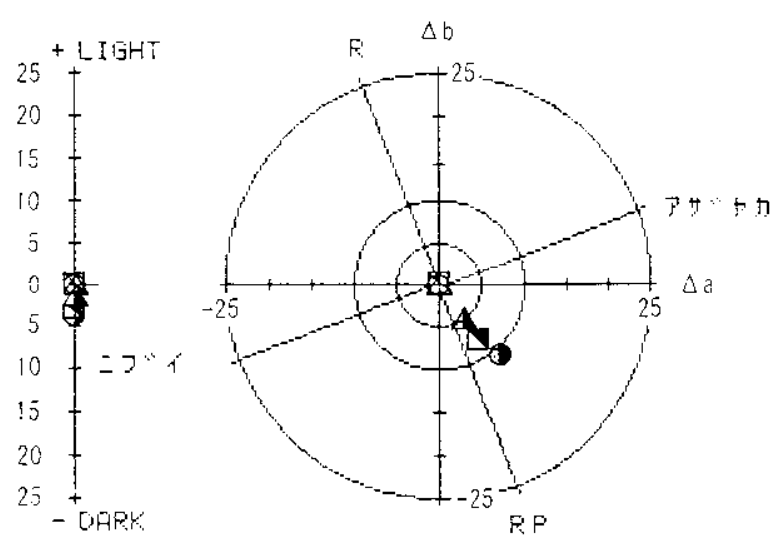

図 12 セルロースパウダー抽出・水洗と酸処理の比較 

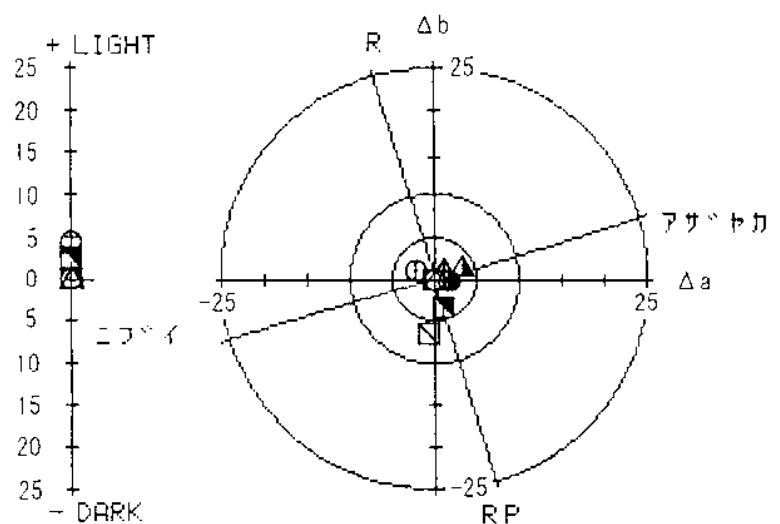

图 13 直接抽出とセルロースパウダー抽出の比較

では染着すると考えられる。酶酸を用いた場合には、染色 残液の $400 \mathrm{~nm}$ 付近の吸光度が低下することからもこのこ とが示唆される。(3)セルロースパウダー抽出では、結果 的に 2 回の抽出を行っているので色素濃度が低下し、従っ ていずれの酸でも直接抽出に比較すると薄く染まっている。 烏梅、クエン酸では、色相、彩度に大きな変化は認められ ず、酶酸では、直接抽出に比べると赤紫方向への偏りすな わち青味を帯びるようになり、セルロースパウダーにより 黄色色素が除去されていることがわかる。(4)酸の種類に よらず染色後の酸処理によって青味が強くなり、濃色とな る。

表 2 は最大吸収波長 $(518 \pm 4 n m)$ における染色布の K/S 值を示したものである。染色条件により最大吸収波長が幾 分異なるので正確な比較とはならないが、酸処理すること によって染色濃度が高くなり、酢酸を用いた場合が最も濃 色になることか認められる。

烏梅を使用すると深く美しく染まるとか、色を深く鮮や かにするとか、染色後、烏梅で処理すると色が訝えて鮮や かになるとかいわれてきた。これまでの実験結果から、酢 酸に比較すると烏梅を用いた場合は黄味か減少する。また 酸処理すると烏梅に関わらず黄味が減少し、青味か増すと ともに濃色となる。光の理由はこの実験結果だけではわか らないが、深く鮮やか、冴えて鮮やか」ということは、 黄色色素か染まっていない、赤色色素のカルタミンの染着 濃度が高いということのように思われる。

表 2 最大吸収波長における K/S 值

\begin{tabular}{|c|c|c|c|c|}
\hline \multirow{2}{*}{ 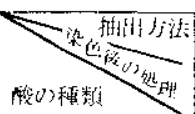 } & \multicolumn{2}{|c|}{ 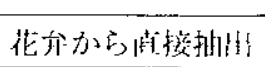 } & \multicolumn{2}{|c|}{ 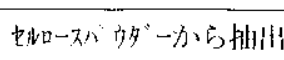 } \\
\hline & 水洗 & 股処理 & 水洗 & 酸处时 \\
\hline 悲梅 & 1.43 & 1.67 & 1.05 & 1.54 \\
\hline クコンン膈 & 1.48 & 1.62 & 1.34 & 1.50 \\
\hline 酶酸 & 1.75 & 2.45 & 1.61 & 2.04 \\
\hline
\end{tabular}

\section{6.おわりに}

合成染料モーブか渶国の若き研究者パーキンによって偶 然、発見されたのが約 150 年前、乥れまでは何千年もの長
きに亘ってわずか 30 種類ほどの天然染料によって染色が 行われてきた。光の染色方法は長い間の経験を積み重ねな がら工夫されてきたものである。しかし、簡単な合成方法、 安価な原料、簡単な染色方法、鮮やかな色、弚れまでの天 然染料と比へてて大きな利点のある合成染料が次々に誕生し 天然染料は衰退した。最近では、長い使用の歴史をもつこ とによる安全性への信頼、環境への配慮、薬効への期待、 鮮明ではないが柔らかい独特の色合いから天然染料を見直 す動きがあり、少しずつ研究されるようになってきた。

紅花も堅ろう度が低いという欠点を改良し、経験を頼り にする染色方法を合理的な方法に改善すれば、弚の色の美 しさ故に使用価值も高まってくるだろう。天然染料が合成 染料に取って代わられたように、将来、天然染料が合成染 料に取って代わるということはまずなかろうが、天然染料 の研究を通して新たな発見を期待したい。

\section{参考文献}

1) J.ツァーン、染色工業、26、551(1978)〔Bayer Farben Revueより転載了

2) J.ツァーン、染色工業、27、19(1979).

3）奈良県教育委員会文化財保存課、烏梅製造記録作成(4) 烏梅产の利用 (2001).

4) J . ツァーン、染色工業、28、248(1980).

5）難波恒雄、染織 $\alpha 、 N 0.183 、 32(1996)$.

6) 木村光雄、染色工業、37、323(1989).

7) Preisser, J. pr. Chem ., 32, 142(1844).

8) Schlieper, Ann., 58, 357(1846).

9) Malin, Ann., 36, 117(1897).

10) Radeliffe, J. Soc. Dyers, 13, 158(1897).

11) T. Kametaka, Tokyo Kagaku Kaishi, 27, 1202(1906).

12) T. Kametaka and A.G. Perkin, J. Chem. Soc., 1415 (1910).

13) 黑田チカ、日本化学会誌、51、237(1930).

14) T. R. Seshadri and R.S. Thakur, Curr. Sci., India, 29, 214 (1960).

15) H. Obara and J. O nodera, Chem. Lett., 201(1979).

16) 小原平太郎、小野寺準一、佐藤慎吾、山形大学紀要 (工 学)、22、91(1993).

17) M. Shimokoriyama and S. Hattori, Arch. Biochem. Biophy., 54, 93(1954).

18）長嶋直子、小笠原真次、片山 明、日本家政学会第 54 回大会研究発表要旨集、183(2002).

19）吉岡常雄、工程写真によるやさしい植物染料入門、 紫紅社(1982).

20) http : //mytown. A shahi . com/nara/news01. asp?c $=5 \&$ $\mathrm{kiji}=273$

21）奈良県教育委員会文化財保存課、烏梅製造記録作成 (1) 烏梅弚の概要 (1997). 